УДК 902.2 (477.54)

DOI: https://doi.org/10.33782/eminak2020.1(29).382

\title{
ДІЛЯНКА З РІЗЦЯМИ НА ПІЗНЬОПАЛЕОЛІТИЧНІЙ СТОЯНЦІ БІЛЯ С. КАМ'ЯНКА
}

\author{
Ірина Сніжко \\ Український державний університет залізничного транспорту (м. Харків, Україна) \\ e-mail: isnizhko@ukr.net \\ ORCID: https://orcid.org/0000-0002-7797-9494
}

Пізньопалеолітична стоянка біля с. Кам'янка Ізюмського району Харківської області відкрита 2004 р., досліджена площа становить $225 \mathrm{M}^{2}$, колекція нараховує 9533 артефакти. Культурний шар корелюється із верхньопричорноморським підгоризонтом.

На ділянці, дослідженої 2019 р., відзначено скупчення різців - 7 екз. на 3 м². Знаряддя представлені переважно двогранними серединними типами, $\epsilon$ двогранний кутовий і подвійний різець. Друга особливість цієї ділянки - наявність великої кількості фрагментів скам'янілого дерева.

Ключові слова: пізній палеоліт, Кам'янка, різці, скам'яніле дерево

Пізньопалеолітична стоянка біля с. Кам'янка Ізюмського району Харківської області була відкрита під час розвідок, що проводились експедицією Харківського історичного музею у 2004 р. під керівництвом I.А.Сніжко. Пам'ятка знаходиться на мисі при впадінні в р.Сіверський Донець невеличкої правої притоки р.Суха Кам'янка, в 1,5 км на південний схід від с. Кам'янка. Мис являє собою високу горизонтальну терасу, що піднята над рівнем р. Сіверський Донець на 8-10 м.

Ця територія, що знаходиться в середній течії р. Сіверський Донець, неодноразово обстежувалась у попередні роки. У 1941 р. М.В.Сібільов, оглядаючи ділянку підвищення правого берега р. Сіверський Донець праворуч гирла р. Суха Кам'янка, відзначив наявність тут відщепів і поодиноких нуклеусів. У його щоденнику є запис: «...по-видимому, стоянка времени бронзы и, возможно, палеолитическая, находятся

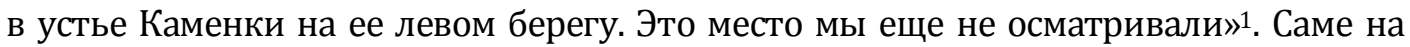
цьому місці, яке М.В. Сібільов не встиг оглянути, в 2004 р. і було відкрито пізньопалеолітичну стоянку.

У 1950 р. І.Ф. Левицький і Д.Я. Телегін під час розвідок обстежили мис при впадінні р. Суха Кам'янка у Сіверський Донець і відзначили наявність великої кількості обробленого кременю. Розчистка вздовж краю тераси дала 2 скребки, відщепи різних розмірів, уламки кременю2. Тобто, було обстежено частину мису, що безпосередньо примикає до гирла Сухої Кам'янки - тут у 2005 р. нами було закладено шурф № 9, що дав матеріал часу енеоліту-бронзи. Незрозуміло, чому зачистку було зроблено на бровці тераси вздовж берега Сіверського Дінця, хоча за топографією видно, що зруч-

\footnotetext{
1 Сибилев Н.В. Экскурсии 1941 г. Дневник // Науковий архів Інституту археології Національної Академії наук України (НА ІА НАН України). А. Ф. № 16. С. 67-69.

2 Левицкий И.Ф. Дневник исследований в районе среднего Донца (Среднедонецкая археологическая экспедиция 1950 г.) // НА ІА НАН України. И. А. 1950/6. № 1240. С. 23-25.
} 
не місце для стоянки розташоване приблизно в 200 м від річки на південь, власне там, де було зафіксовано наявність культурного шару у 2004 р.

Стаціонарні дослідження пам'ятки, розпочаті 2005 р., тривають по теперішній час. Загальна відкрита розкопом площа становить 225 м², колекція знахідок нараховує 9533 артефакти.

Культурний шар визначається рівнем поширення знахідок. Він розтягнутий по вертикалі, не має специфічного забарвлення, представлений дрібними фрагментами кісток тварин, шматочками червоної та жовтої вохри, розщепленим кременем, що демонструє всі стадії обробки від жовна до знаряддя. Найбільша концентрація знахідок спостерігається частково у темно-коричневому, світло-коричневому та жовтувато-палевому суглинку, окремі артефакти зустрічаються також у гумусовому горизонті й у типовому лесі. Відзначається деяке падіння рівня залягання знахідок 3 півдня на північ і з заходу на схід, що відповідає зниженню рельєфу в бік річок Сіверський Донець і Суха Кам'янка, а також пов'язане з особливостями грунтоутворення у голоцені.

Культурний шар пошкоджений внаслідок дії наступних постгенетичних факторів: відсутність консервації артефактів після завершення функціонування пам'ятки; переміщення артефактів вгору внаслідок процесів замерзання та відтаювання; вплив делювіальних процесів; діяльність риючих тварин. Завдяки використанню методу мікростратиграфії встановлено, що формування ініціального рівня відкладання знахідок можна визначити як одноактний процес. На ділянках, де можна простежити рівень первинного відкладання знахідок, він корелюється з жовтуватопалевим суглинком, що відноситься до верхньопричорноморського підгоризонтуз

Планіграфічна структура культурного шару на дослідженій ділянці квадратів -110-А-Щ включає скупчення крем'яних артефактів, які, вірогідно, відповідають робочим місцям, де відбувалось розколювання кременю (рис. 1). На користь цього свідчать також і випадки ремонтажу у скупченнях.

На основі результатів палінологічних досліджень було проведено реконструкцію природного середовища, що відповідало часу існування стоянки. Встановлено, що означена територія знаходилася у межах степової зони із субперигляціальним кліматом, який був значно холоднішим і сухішим за сучасний. Рослинний покрив був одноманітним, бідним за складом і розрідженим. Про холодний клімат свідчить наявність серед деревних порід лише бореальних та аркто-бореальних елементів. У долині була присутня деревинна рослинність, а степові ценози були ксеромезофітними різнотравно-злаковими та злаковими. За стратиграфічними спостереженнями та результатами палінологічного аналізу можна припустити, що існування пам'ятки припадає на причорноморський етап пізнього плейстоцену та знаходиться у межах переходу від ранньопричорноморського стадіалу до початку пізньольодовиків'я4.

Крем'яні знахідки мають добрий стан збереженості, не обкатані, поверхня вкрита шаром патини від молочно-білої до легкої блакитної димчастої. В якості сировини

\footnotetext{
3 Сніжко І.А. Дослідження пізньопалеолітичних пам'яток з пошкодженим культурним шаром // Старожитності 2010: Харківський історико-археологічний щорічник. Харків: Харківське історикоархеологічне товариство; ТОВ «НТМТ», 2010. Вип. 9. С. 111-114.

4 Герасименко Н.П., Снежко И.А. Реконструкция природной среды обитания человека на позднепалеолитической стоянке у с. Каменка // Старожитності 2012: Харківський історикоархеологічний щорічник. Харків: Харківське історико-археологічне товариство; ТОВ «НТМТ», 2012. Вип. 11. С. 100-102.
} 
використовувався темно-сірий, майже чорний напівпрозорий крейдяний високоякісний кремінь місцевого походження. На території стоянки відбувався повний цикл обробки крем'яної сировини - від заготовок нуклеусів до залишкових ядрищ та утилізованих знарядь. Нуклеуси торцевидної, призматичної, кубовидної форми демонструють ударну техніку сколювання. Найбільш виразною $є$ група торцевих нуклеусів з виступаючою тильною частиною. Деякі нуклеуси мають сліди характерної зірчастої забитості, що виникла внаслідок використання їх в якості відбійника. Процес виготовлення та підживлення нуклеусів представлено реберчастими сколами та відщепами. Значна кількість заготовок і сколів з жовновою кіркою свідчать, що джерело добування кременю знаходилось порівняно недалеко від стоянки. Метою первинного розщеплення були заготовки у вигляді видовжених пластинок і відщепів. Вироби з вторинною обробкою представлені двогранними серединними та боковими різцями, кінцевими скребками, скребловидними знаряддями, проколками, виїмчастими знаряддями. Невелику, але дуже характерну групу утворюють мікропластинки з притупленим краєм. Особливий інтерес становлять наконечниками з боковою виїмкою (один цілий і два у фрагментах), які не мають аналогій у колекціях пам'яток суміжних територій. Загалом знарядь із вторинною обробкою трохи більше 1\%. Їх незначна кількість типова для пам'яток, розташованих поблизу виходів крем'яної сировини, де первинна обробка відбувалась безпосередньо на території поселення. В цілому набір знарядь характерний для кола епіграветських пам'яток, хоча присутність у ньому наконечників з виїмкою і викликає ряд питань.

До 2019 р. розкопки стоянки відбувались суцільною площею: нові ділянки прирізались до вже вивчених. Але цього року в 20 м на захід від дослідженої ділянки було закладено новий розкоп. Його розташування було обумовлене знахідками, зробленими при прокопуванні шурфу № 17 у 2018 р. На загальній сітці квадратів, що прийнята на пам'ятці, новий розкоп отримав нумерацію 29-31-3-і. Горизонт залягання знахідок тут відповідає стратиграфічній ситуації, що спостерігалась у попередні роки на дослідженій ділянці. Поодинокі знахідки з'являються майже від поверхні, концентруються в коричневому та жовтувато-палевому суглинку, незначна кількість у типовому лесі. Отже, розповсюдження знахідок можна, як і на раніше дослідженій ділянці, пов'язати з верхньопричорноморським підгоризонтом. Крем'яна сировина тут має ті ж характеристики: це місцевий якісний кремінь темно-сірого кольору, переважна більшість предметів вкрита шаром патини від густої білої до легкої блакитної димчастої.

3 ділянки квадратів 29-31-з-і походить колекція, сформована матеріалами із шурфу № 172018 р. та розкопу 2019 р. Вона налічує 286 предметів і представлена наступними групами: пренуклеуси та нуклевидні уламки (6 екз.), сколи формування та підправки нуклеусів (52 екз.), нуклеуси торцеві (2 екз.), відщепи (включаючи первинні та напівпервинні - 22 екз.), відщепи пластинчасті (12 екз.), пластинки цілі та у фрагментах двох- і трьохскатні (26 екз.), мікропластинки цілі та у фрагментах двохта трьохскатні (10 екз.), різцевий відщепок, лусочки (77 екз.), уламки (71 екз.) та знаряддя із вторинною обробкою (9 екз.). Останню групу складають 7 різців (5 серединних, кутовий та подвійний), скребок кінцевий на двоскатній пластині та мікропластинка з ретушованою ділянкою. На площі квадратів 29-31-3-і знахідки не утворюють чітко визначених скупчень, хоча впадає в очі їх більша концентрація в кв. 30-3-и, 29-и (рис. 1). 
Особливістю ділянки квадратів 29-31-з-і в порівнянні з усією дослідженою раніше площею $є$ доволі значна, як для цієї пам'ятки, концентрація різців - 7 екз. фактично на трьох квадратних метрах. У колекції з квадратів -1-10-А-Щ і підйомного матеріалу, зібраного за всі роки навколо розкопу всього 20 різців. Знаряддя із квадратів 29-31-з-і представлені переважно двогранними серединними типами, є двогранний кутовий та подвійний різець (рис. 2). В якості заготовок було використано відщепи та масивний напівпервинний скол формування/підправки нуклеусу. На плані (рис. 1) різці позначені червоним кольором. Із кв. 31-з походить двогранний кутовий різець (рис. 2,2), знайдений майже на східному його кордоні. У північній частині кв. 30-з знайдено серединний різець (рис. 2, 4), а також різцевий відщепок. 3 кв. 30-и (шурф № 17) походять два двогранних серединних різця (рис. 2, 6-7), з кв. 29-и - двогранний серединний різець (рис. 2, 1). I ще два - двогранний серединний і подвійний - знаходились майже поруч у кв. 30-і (рис. 2, 3, 5). Відстань між всіма різцями не перевищує кілька десятків сантиметрів. Така концентрація знарядь одного типу на невеликій ділянці може бути свідченням їх виготовлення та/або використання.

Друга особливість ділянки квадратів 29-31-з-і - наявність великої кількості фрагментів скам'янілого дерева. Визначити цей матеріал допоміг А.В. Матвєєв - доктор геологічних наук, завідувач кафедри геології Харківського національного університету імені В. Н. Каразіна. На дослідженій у попередні роки площі 216 м² (квадрати -1-

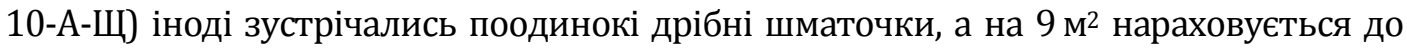
сотні фрагментів. Розмір їх переважно 3-5 до 10 см завдовжки і 2-5 см завширшки, $\epsilon$ більш дрібні фрагменти. Колір від темного сірувато-коричневого до жовтуватосірого, з добре видною шаруватістю. Деякі фрагменти справляють враження оброблених, з рівними або заокругленими краями.

На мисі, де розташована пам'ятка, на поверхні зустрічаються уламки скам'янілого дерева, $є$ навіть великий фрагмент стовбура. До того ж селище Олексієво-Дружківка з геологічною пам'яткою загальнодержавного значення «Дружківські скам'янілі дерева» знаходиться в 60 ка від Кам'янки.

У середній течії Сіверського Дінця наявність скам'янілої деревини була відзначена ще наприкінці 19 ст. М. Крендовский описав та визначив деякі зразки, що походять 3 цієї території. Він, зокрема, писав: «К араукаровым деревьям (Araucaritis inflatus) меловой формации следует отнести несколько образчиков окаменелых стволов из с. Каменка и окрестностей г. Изюма. Эти деревья проникнуты твердым кремнистым веществом, похожим на сердолик или халцедон, и окрашены в пепельно-серый или рыжевато-коричневый цвет. ...на продольном разрезе отчетливо выступают волокна древесины,... по направлению которых кремнистая масса ствола распадается на прямоугольные отдельности и тонкие пластинки». Скам'яніла деревина з кам'яновугільного пісковику із околиць Святогорську та Дружківки визначена ним як Araucarites, з кам'яновугільних осадових порід слободи Петровської Araucarites orientals 6 .

Отже, відомо, що у цьому районі $\epsilon$ місцезнаходження скам'янілого дерева. Дивує не сам факт присутності його фрагментів в культурному шарі, а концентрація на обмеженій ділянці.

\footnotetext{
${ }^{5}$ Крендовский М.Е. Описание окаменелых деревьев, собранных преимущественно на юге России. Харьков, 1880. Ч. 2. С. 13-14.

6 Там же. С. 30.
} 
Скам'яніле дерево використовувалось в якості сировини для виготовлення знарядь у різних регіонах світу й у різні часи. Так, на середньопалеолітичній стоянці ВР177 Козяча Гора, що розташована в пустелі Баюда у Північному Судані, скам'яніле дерево було використано для виготовлення майже чверті знарядь (24\% скам'яніле дерево, кварц 19\%, кварцитний пісковик 18\%, кремінь 16\%, вулканічне скло 12\%, алевроліт 10\%, халцедон 1\%). Дослідників здивувала значна кількість виробів зі скам'янілої деревини, нечисленної в цьому районі, на противагу кременистим і вулканічним породам, що зустрічаються скрізь навколо стоянки. Найважливіші вироби, що підтверджують таксономічну приналежність стоянки леваллуа - мустьєрські наконечники та біфаси - виготовлені переважно зі скам'янілої деревини, рідше - 3 кременистих порід або кварцу7.

Скам'яніле дерево у великій кількості присутнє в Єгипетських західних і східних пустелях і на Сінаї. Великий «ліс» скам'янілих дерев розташований поблизу Каїру. Багато видів скам'янілих дерев Єгипту ідентифіковано ботаніками. Скам'яніле дерево дуже твердий матеріал, його складно обробляти, тому відомо лише кілька випадків його використання у палеоліті на цій території. У неоліті зафіксовано його використання в якості відбійника. Також воно представлене серед матеріалів Бодарійської культури (4500-3250 рр. до н.е.) ${ }^{8}$.

На північному сході Індії, у штаті Трипура, в радіусі 45 км навколо міста Агартала досліджено 25 поселень кам'яного віку, що датуються в хронологічних межах від 35 тис. років тому до неоліту. Колекція артефактів включає біфаси, струги, скребки, наконечники, реберчасті знаряддя велику кількість відщепів тощо. Для виготовлення 98\% знарядь в якості сировини було використано скрем'янілу деревину. Ї̈̈ розколювання відбувалось із нахилом до поздовжньої вісі або поперек неї, можливо, щоб контролювати розмір відщепів. Скрем'яніле дерево важко розколювати, хіба що вздовж вісі, що перетинає річні кільця, відповідно головні типи знарядь визначались пласкою поверхнею. Левалуазська техніка спостерігалась дуже рідко9.

Дослідження палеоіндіанської пам'ятки в регіоні Палмер Дівайд, Колорадо, найбільш ранні шари якої датуються часом 7450-4950 років тому, показало, що скам'яніле дерево використовувалось в якості сировини для виготовлення знарядь в 75,3\% випадків (ліпарит 15,6\% та кварцит 9,1\%)10.

Перелік пам'яток, де скам'яніле дерево використовувалось як сировина для виготовлення знарядь можна продовжувати. Чи потрапить до нього стоянка біля с. Кам'янка - покажуть майбутні дослідження.

Отже, розкопки нової ділянки стоянки біля с. Кам'янка дали цікавий матеріал, який не тільки доповнив колекцію знарядь, але й надав інформацію щодо просторової структури пам'ятки.

\footnotetext{
7 Masojć M. Ferst note on the discovery of a stratified Palaeolithic site from the Bayuda Desert (N-Sudan) within MAG concession // Der Antike Sudan. Mitteilungen der Sudanarchäologischen Gesellschaft zu Berlin e.V. 2010. Heft 21. P. 66-68.

${ }^{8}$ Aston B.G., Harrell J.A., Shaw I. Stone // Ancient Egyptian Materials and Technology. Cambridge: Cambridge University Press, 2000. P. 28.

${ }^{9}$ Ramesh N.R Discovery of Stone Age tools from Tripura and its relevance to the prehistory of Southeast Asia // Bulletin of the Geological Society Malaysia. 1986. Vol. 20. P. 289-310.

10 Mayo K.V. Welcome Home Ranch Rockshelter: Examinations of Prehistoric Cultural Transitions in the Palmer Divide, Colorado. A Thesis Presented toThe Faculty of Social Sciences University of Denver. 2014. P. 260. Electronic eses and Dissertations. 411. URL: https://digitalcommons.du.edu/etd/411/
} 


\section{REFERENCES}

Aston, B.G., Harrell, J.A. \& Shaw, I. (2000). Stone. In Ancient Egyptian Materials and Technology (pp. 577). Cambridge: Cambridge University Press.

Gerasimenko, N.P. \& Snezhko, I.A. (2012). Rekonstruktsiia prirodnoi sredy obitaniia cheloveka na pozdnepaleoliticheskoi stoianke u s. Kamenka [Paleoenvironmental Reconstruction of the Upper Paleolithic Site Near Kamyanka Village]. Starozhytnosti 2012: Kharkivskyi istoryko-arkheolohichnyi shchorichnyk. (Vol. 11, pp. 100-102). Kharkiv: Kharkivske istoryko-arkheolohichne tovarystvo; TOV «NTMT» [in Russian].

Krendovskii, M.E. (1880). Opisanie okamenelykh derevev sobrannykh preimushchestvenno na iuge Rossii [Description of petrified trees collected mainly in the South of Russia]. Kharkov [in Russian].

Levitskii, I.F. (1950). Dnevnik issledovanii v raione srednego Dontsa Srednedonetskaia arkheologicheskaia ekspeditsiia $1950 \mathrm{~g}$. [Research diary of the middle Donets region (Srednedonetsk archaeological expedition 1950)]. In: Naukovyi arkhiv Instytutu arkheolohii Natsionalnoi Akademii nauk Ukrainy. I. A. 1950/6. 1240. [in Russian].

Masojć, M. (2010). Ferst note on the discovery of a stratified Palaeolithic site from the Bayuda Desert (N-Sudan) within MAG concession. Der Antike Sudan. Mitteilungen der Sudanarchäologischen Gesellschaft zu Berlin e.V. 21. 63-70.

Mayo, K.V. (2014). Welcome Home Ranch Rockshelter: Examinations of Prehistoric Cultural Transitions in the Palmer Divide, Colorado. A Thesis Presented to the Faculty of Social Sciences University of Denver. Electronic eses and Dissertations. 411. Retrieved from https://digitalcommons.du.edu/etd/411/

Ramesh, N.R. (1986). Discovery of Stone Age tools from Tripura and its relevance to the prehistory of Southeast Asia. Bulletin of the Geological Society Malaysia, 20, 289-310.

Sibilev, N.V. (1940). Ekskursii 1941 g. Dnevnik [Excursions 1941. Diary]. In: Naukovyi arkhiv Instytutu arkheolohii Natsionalnoi Akademii nauk Ukrainy. A. F. 16. [in Russian].

Snizhko, I.A. (2010). Doslidzhennia piznopaleolitychnykh pam'iatok z poshkodzhenym kulturnym sharom [Investigation of the Upper Paleolithic Sites with Damaged Cultural Layer]. Starozhytnosti 2010: Kharkivskyi istoryko-arkheolohichnyi shchorichnyk (Vol. 9, pp. 111-114). Kharkiv: Kharkivske istoryko-arkheolohichne tovarystvo; TOV «NTMT» [in Ukrainian].

\section{Iryna Snizhko}

(Ukrainian State University of Railway Transport, Kharkiv, Ukraine)

ORCID: https://orcid.org/0000-0002-7797-9494

\section{An Area With Burins on the Late Paleolithic Site Near the Kamianka Village}

The Late Paleolithic site near the Kamianka village of the Izium district of the Kharkiv region was found in the 2004. The total excavation area is 225 square meters; the collection of findings consists of 9533 artefacts.

The cultural layer is determined by the findings spread level; it doesn't have any specific colour, it contains animal bones fragments, pieces of ochre, chipped flint. The greatest concentration of findings is observed in the pale-yellowish loam, which belongs to the Upper Black Sea region subhorizon. The cultural layer planigraphical structure contains assemblage of the flint artefacts which probably correspond to the places of work.

On the site territory the full cycle of the flint raw material processing took place. The tools set contain burins, end-scrapers, thumb flint-like and notched tools, borers, backed microblades. On the whole it is typical for the Epigravettian sites.

The particularity of the area researched in 2019 is quite sizable, as for this site , burins concentration - 7 exemplars on three square meters comparing to 20 exemplars from the whole excavated area and surface finds. The tools are represented primary with straight dihedral burin types; there are also an angle dihedral burin and a double burin. As drafts, flakes and semiprime core trimming element were used. The distance between all burins doesn't exceed several dozens of centimetres. Such concentration of the tools of one type on a small area may witness for their manufacturing and/or usage.

The second particularity of this area is presence of big amount of silicified wood fragments. On the area researched in the previous years, single small pieces were sometimes found, and on 
9 square meters they count up to hundred fragments. Some of them resemble to the processed ones, with even or rounded borders. It is known that in the region of the middle reaches of the Siverskyi Donets there is a location of silicified wood. The amazing thing is not the silicified wood fragments presence in the cultural layer, but its concentration in a narrow area.

The excavations of the new site area near the Kamianka village gave interesting material, which not only replenished the tools collection, but also provided information on the site spatial structure.

Keywords: Late Paleolithic, Kamianka, burins, silicified wood

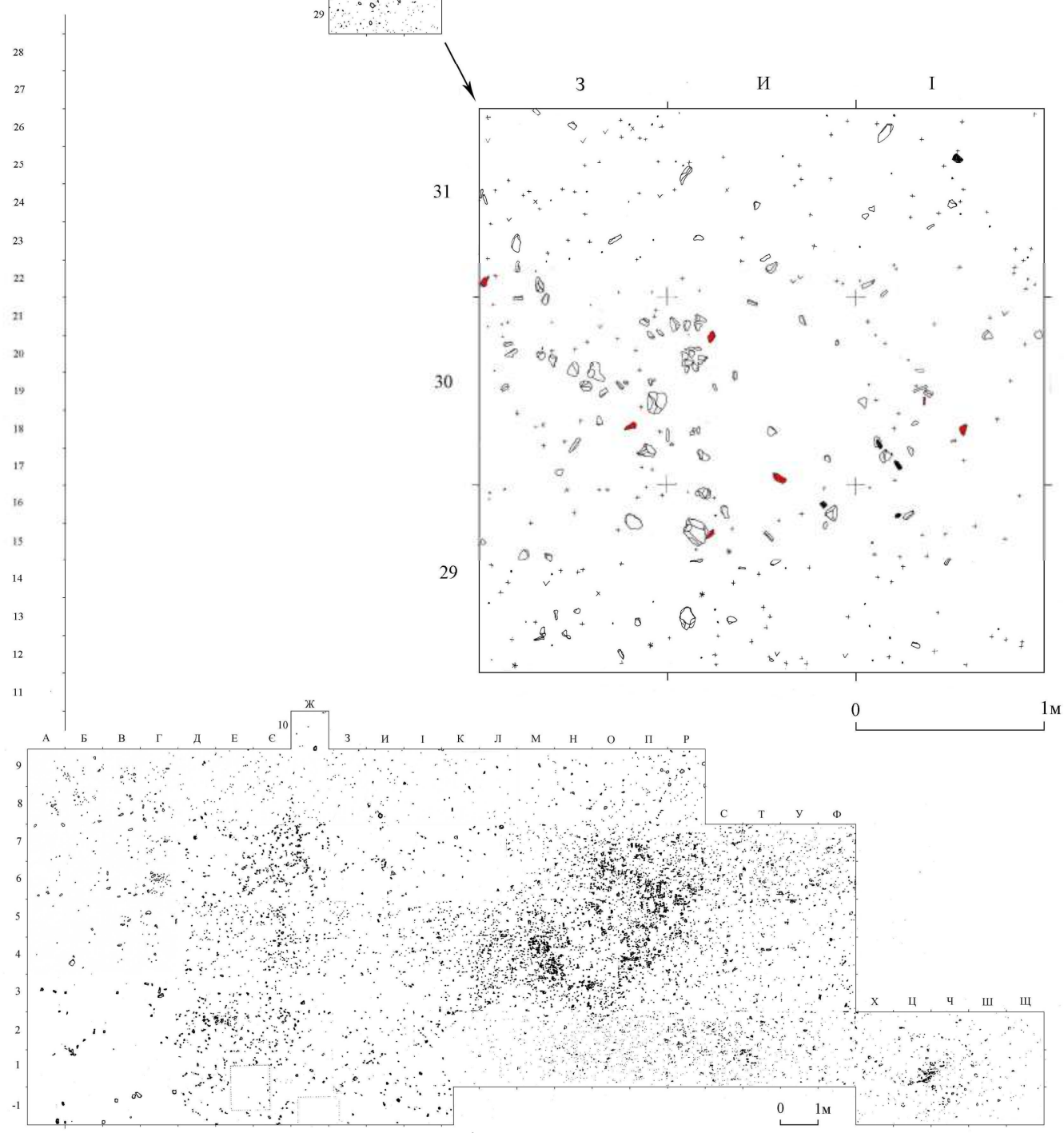

Рис. 1. Кам'янка. Розташування знахідок на досліджених ділянках 

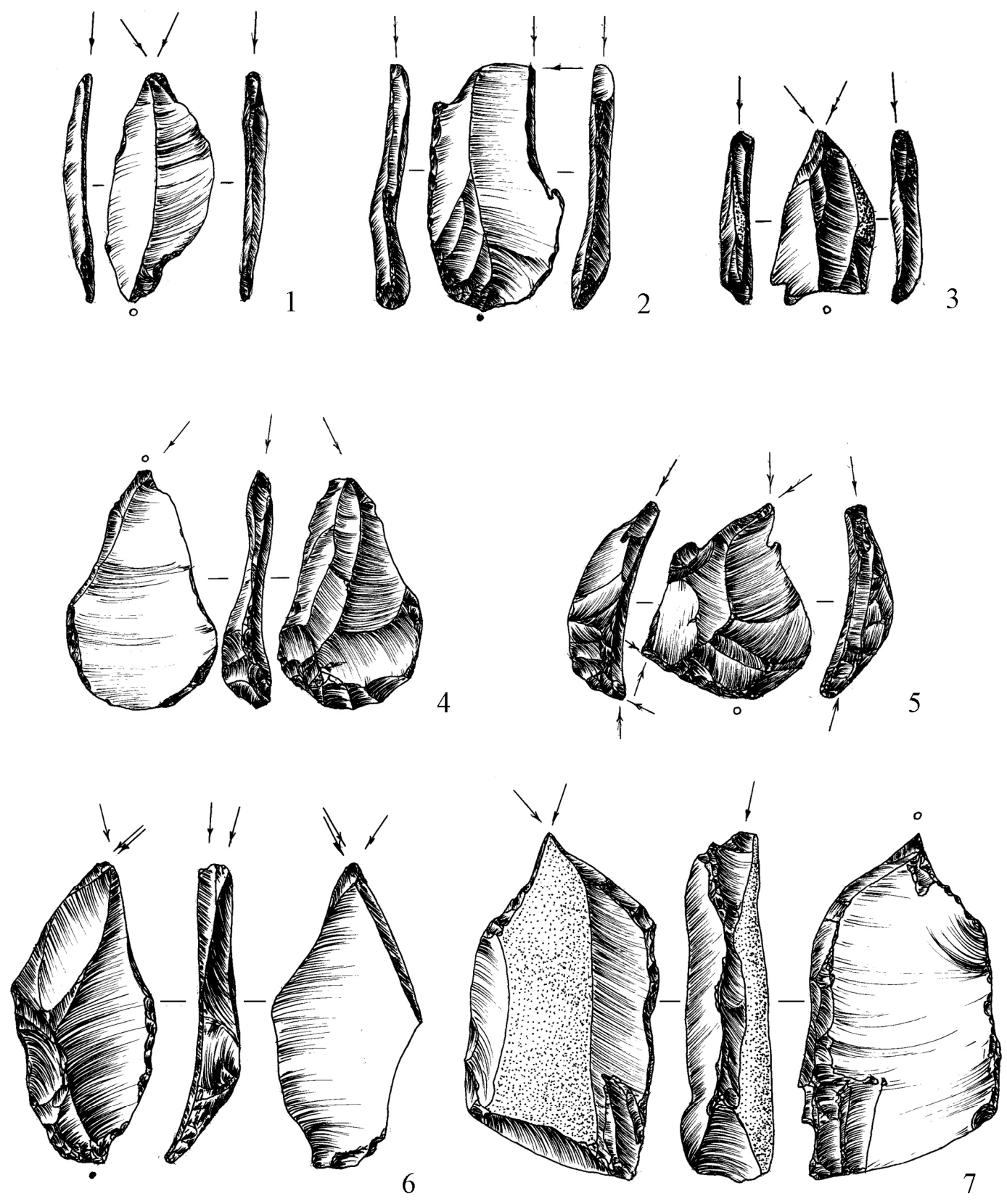

$0 \quad 1 \mathrm{~cm}$

Рис. 2. Кам'янка. Різці з ділянки 29-31-з-і 